\title{
Eurasian Journal of Forest Science
}

2020 8(1): $35-53$

http://dergipark.gov.tr/ejeifs

\section{Tree species composition, structure and regeneration status in Munessa natural forest, Southeastern Ethiopia}

\author{
Annissa Muhammed Ahmedin ${ }^{1,2, *}$ (iD, Eyasu Eliasb ${ }^{2}$ (iD \\ ${ }^{l}$ Department of Natural Resource Management, College of Agriculture and Environmental Science, Arsi University, \\ Assela, Ethiopia \\ ${ }^{2}$ Centre for Environmental science, College of Natural and Computational science, Addis Ababa University, Addis \\ Ababa, Ethiopia \\ Corresponding author:annissamuhammed@gmail.com
}

\begin{abstract}
Munessa forest is one of the undifferentiated afromontane forests in Ethiopia and that has threatened by deforestation, open grazing system and illegal logging operations. This study aimed to estimate the forest stand structure, tree species composition and diversity of tree species and regeneration status in Munessa natural forest. Vegetation data were collected from 54 plots of $20 \mathrm{~m}$ x $20 \mathrm{~m}$ for trees and 162 subplots of $5 \mathrm{~m} \mathrm{x} 5 \mathrm{~m}$ for seedlings and saplings laid along six parallel transect lines. Floristic structure, basal area (BA), Importance value index (IVI) and species prioritization were analyzed using spreadsheet programs. Correlation coefficients, vegetation classification, Shannon diversity index and evenness were analyzed using RStudio 3.2.2. A total of 61 tree species (41 families) were recorded. Fabaceae was the most dominant family represented by four species followed by Oleaceae and Rutaceae, each having three species. The hierarchical cluster analysis revealed four community types, of which Syzygium guineense - Croton macrostachyus community type, exhibited the highest species diversity and evenness. The Shannon diversity and evenness index for the entire study area was 2.6 and 0.39 respectively. The correlation between elevation and species richness was negative and insignificant $(\mathrm{r}=-0.545, \mathrm{p}<0.05)$. The densities of seedlings, saplings and mature trees were 6,934, 1,686 and 481 individuals per ha respectively. This indicated that the regeneration status was significantly lower compared to other similar sites. The total BA of the forest was $91.75 \mathrm{~m}^{2}$ per ha and its IVI ranged from 0.62 for Calpurnia aurea (Ait.) Benth. to 70.29 for Podocarpus falcatus (Thumb.) R.B.ex.Mirb. The estimated values of forest structure and regeneration status of the forest indicated that there was a huge disturbance induced by open grazing and illegal tree cutting. Therefore participatory forest management strategies need to be implemented to protect the forest sustainably.
\end{abstract}

Keywords: Basal area, Hierarchical cluster, Importance value index, Regeneration

\section{INTRODUCTION}

Biological diversity is often defined as "the variability among living organisms from all sources including, inter alia, terrestrial, marine and other aquatic ecosystems and the ecological complexes of which they are part; This includes diversity within species, between species and of ecosystems" (Glowka et al., 1994). Forests in the tropical region constitute the most diverse plant communities on earth (Devi and Yadava 2006). However, the variety of tree species in the tropics is threatened partially by the introduction of exotic plant species and anthropogenic disturbances in the course of the last century (Paritsis and Aizen, 2008). The Ethiopian highland contributes more than $50 \%$ 
of the land area in Africa with afromontane vegetation (Abebe, 2008), of that the undifferentiated afromontane forests form the largest part. The undifferentiated afromontane forests are either mixed Juniperus - Podocarpus (gymnosperm genus) forests or predominantly Podocarpus forests, each with a component of broad-leaved species. They occur in both northwestern and southeastern highland at altitude ranges between 1500- $2700 \mathrm{~m}$ (Friis and Lawesson, 1993). About $35 \%$ of the land area of Ethiopia was once covered with high forests but it reduced to $16 \%$ in 1950 s, $3.6 \%$ in 1980 s, and to $2.3 \%$ in 2003(Tesfaye Hunde, 2007, Admassu et al., 2016). The flora of Ethiopia encompasses about 6,027 vascular plant species of which $10 \%$ are endemic (Kelbessa and Demissew, 2014). This distribution makes the country the fifth largest floral composition in tropical Africa (Didita et al., 2010). However, the rich biodiversity of the country is under serious threat due to deforestation, overgrazing, shifting cultivation, forest fire and poaching of forest reserves (IBC, 2009).

Munessa natural forest is one of the major timber supplier forests of the country and ironically puts the natural forest under severe pressure from illegal logging activities. In addition, the good transportation facilities between the forest and the timber market in the capital Addis Ababa favour smuggling of forest products and contribute to the degradation of the natural forest (Duriaux and Baudron, 2016). Moreover, grazing and encroachment due to agriculture activities has become increasingly affecting the area in recent years (Abebe, 2008). To secure the ecological equilibrium of the environment and attain the forest resource necessities, assessment of scientific data on the species composition, stand structure and distribution in the study areas become prime activity, where it has not been attained (Ayalew et al., 2006). Such study has rarely been investigated and their status is not well identified in the study area. Therefore, the objectives of this study was to explore the species structure, composition and regeneration status of trees and to identify the priority tree species for conservation and management interventions in the natural forest of Munessa.

\section{METHODOLOGY}

\section{Study Site Description}

This study was carried out in Munessa natural forest which is one among the three forest districts (Munessa, Gamboo and Shashemene districts) in Arsi forest enterprise. It is a protected forest that is owned by the state and controlled by Oromia Forest and Wildlife Enterprise (OFWE). It is located at 240 $\mathrm{km}$ south of Addis Ababa, Ethiopia (Figure 1) and bounded between $7^{\circ} 25^{\prime} 44^{\prime \prime} \mathrm{N}$ and $38^{\circ} 51^{\prime} 05^{\prime \prime} \mathrm{E}$ geographic coordinate along the eastern escarpment of the Rift Valley. It extends over an altitude ranges from $2100 \mathrm{~m}$ to $2450 \mathrm{~m}$ a.s.l. The total concession area of the enterprise is estimated as 21,384 ha, of which 6,230 ha is plantation forest and 15,154 ha is natural forest. According to the Ethiopian classification of climatic zones, Munessa forest can be classified as Dega (2300-3200 m a.s.l) zones. The area has a bimodal rainfall i.e. the main rainy season is from the end of June to September, and short rainy season is from February to April. The mean annual rainfall of the area is $1075 \mathrm{~mm}$ (18 year average) and the mean annual temperature is $15^{\circ} \mathrm{C}$ (16 year average) (Duriaux and Baudron, 2016). Friis in 1992 described the vegetation of the area as "undifferentiated Afromontane Forest", including varies upland forests with Podocarpus. Mixed broad-leaved deciduous and evergreen trees characterize the forest vegetation in Munessa natural forest. The dominant tree species are Podocarpus falcatus (Thumb.) R.B.ex. Mirb., Prunus africana (Hook.f.) Kalkm, Croton macrostachyus Del., Maytenus addat (Loes.) Sebsebe and Nuxia congesta $\mathrm{R}$. Br. ex Fresen. The soil texture is predominately a slightly acidic and nutrient rich clay-loam that was evolved from volcanic parent material and it was classified as Mollic Nitisols (Fritzsche et al., 2007). 


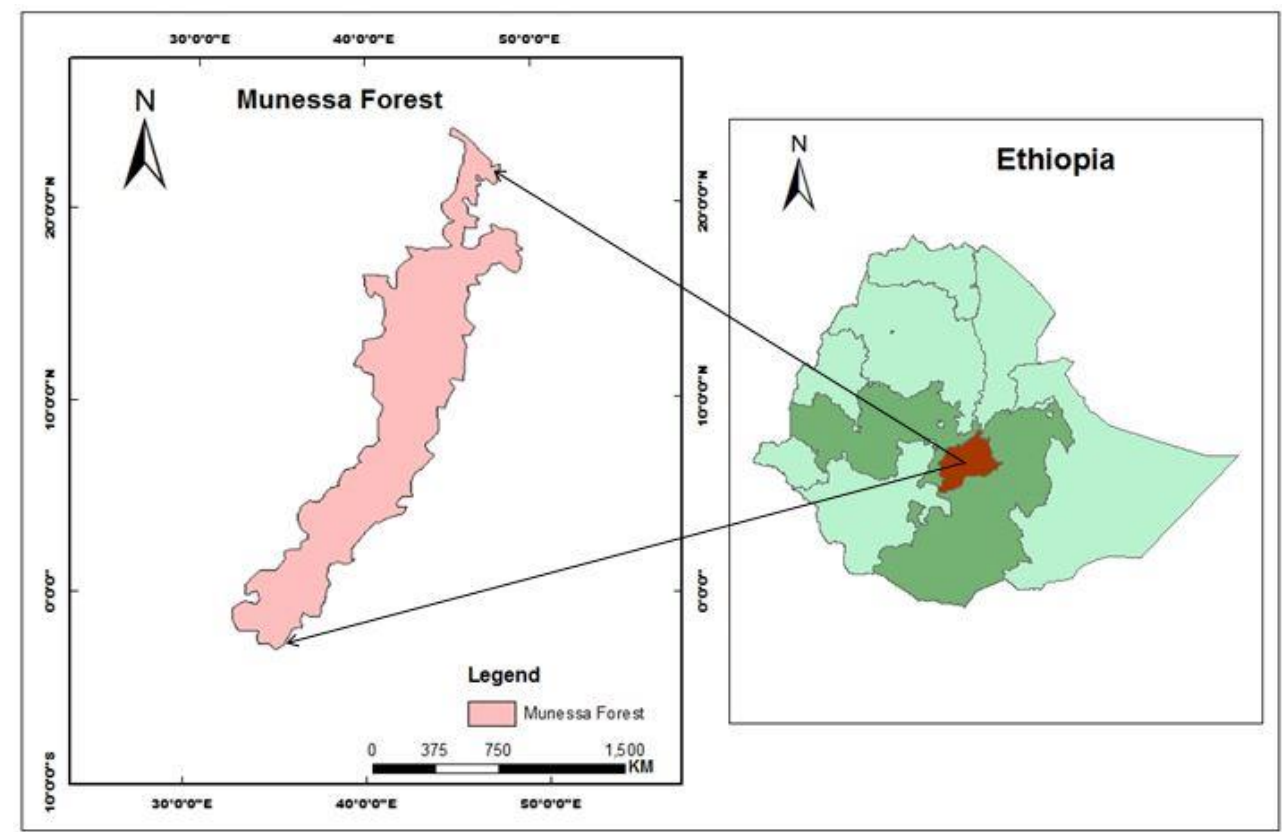

Figure 1. Location of the study area

\section{Sampling design}

Systematic sampling design was set to determine the tree species status of the study site. A $20 \mathrm{~m}$ x $20 \mathrm{~m}$ sample plots were laid along six parallel line transects (having a length of $800 \mathrm{~m}$ ) along the altitudinal gradient at a distance of $100 \mathrm{~m}$ to cover representative samples of the forest. A total of 54 sample plots (9 at each transect) with an area of 2.16 ha each were plotted. The distance between adjacent transects was $250 \mathrm{~m}$. In each plot, data on species name (vernacular and scientific nomenclature), abundance, dominance and evenness of each tree species were recorded. Diameter at breast height (DBH) with DBH $\geq 5 \mathrm{~cm}$ was measured using a tree caliper and diameter tape (Abate, 2003). The heights of all individuals of trees with a $\mathrm{DBH} \geq 5 \mathrm{~cm}$ were measured with a hypsometer (Nikon Laser Rangefinder Forestry Pro). Local and scientific names and number of dead stumps were also recorded. In order to assess vegetation regeneration dynamics, seedlings and saplings counts were undertaken. Three subplots of $5 \mathrm{~m} \times 5 \mathrm{~m}$ : two at the corners and one at the center nested within each $400 \mathrm{~m}^{2}$ main plot (total area $75 \mathrm{~m}^{2}$ per plot) were set to assess abundance and frequency of seedlings and saplings. A total of 162 subplots with total area of 0.40 ha were investigated.

\section{Floristic data collection}

All tree species in each plot were identified and their scientific and vernacular names were recorded on site. Representative plant specimens were collected, numbered and pressed to compile a complete list of species. Then specimens were identified and confirmed at the National Herbarium (ETH), at Addis Ababa University following Edwards et al. (1995, 1997), Tadesse (2004) and Hedberg et al. (2003, 2006, 2009a).

\section{Forest composition and diversity}

Species richness, Shannon-Wiener diversity index and evenness were computed following Maguran 1988 and Krebs 1999. Shannon-Wiener diversity index provides an account of both the abundance and evenness without disproportionately favoring any species as it counts all the species according to their 
frequency (Jost, 2007, Danoff-Burg and Xu, 2008). The value usually falls between 1.5 and 3.5, it rarely exceeding 4.5. To determine floristic similarity between the sample plots, Sørensen's similarity coefficient (SSC) was employed.

\section{Vegetation structure}

$\mathrm{DBH}$, tree height, basal area, relative dominance, relative density, relative frequency and important value index were determined to describe the vegetation structure of the study area following Mueller-Dombois and Ellenberg (1974) and Martin (1995). The number of individuals within each DBH and height class was summed and histograms were constructed to determine the population structure and regeneration status of each woody species using Microsoft Excel.

\section{Regeneration status of tree species}

Floristic composition, number of seedlings, saplings and analysis of their densities in a forest has implications for regeneration and management of a natural forest. The density of seedlings and saplings is considered as a key indicator for determination of regeneration potential of a given forest (Dhaulkhandi et al., 2008). The total density of seedling, sapling and mature trees were determined and the ratio of seedlings and saplings to adult individuals of woody species, as well as the ratio of seedling to saplings were also computed to make a comparison.

\section{Data analysis}

In order to show the differences both in diversity and regeneration levels, further statistical analyses were done for the indices and species densities derived. Single-factor analysis of variance (one-way ANOVA) was determined to detect the significant difference in species evenness and diversity across altitudinal gradients. Simple Linear Correlation and Regression test was performed to investigate the relationships of tree species richness with elevation class. Where there is significant difference, mean separation was achieved through Tukey's B-test at $p<0.05$ level of significance.

\section{Plant community analysis}

Hierarchical cluster analysis were made to classify plant communities based on the cover abundance data and floristic similarities (McCune et al., 2002) using the Cluster and Vegan packages in RStudio 3.2.2. The analysis was based on the abundance data of the species. A hierarchical agglomerative clustering technique was applied using Euclidean distance and Ward's method to classify plots that produced a dendrogram and cluster IDs. After identification of the major clusters, characteristic species of plant communities were identified by importing the cover abundance data matrix and cluster IDs into $\mathrm{R}$ software to produce a synoptic table. The plant communities were named after selecting the species with highest mean cover abundance value in each cluster (Oksanen et al., 2016).

\section{RESULTS AND DISCUSSION}

\section{Tree species composition}

A total of 61 tree species belonging to 41 families were identified of which seven families with nine species and more than ten numbers of individuals each constituted $80 \%$ of total species richness. Having four species, Fabaceae is the most diverse family followed by Oleaceae and Rutaceae with three species each. Based on stand density Euphorbiaceae is the most dominant family with 125 individuals per ha followed by Ulmaceae with 100 individuals per ha. Top seven families having the highest number of individuals were depicted in Figure 2 below. The species richness of the study area varied from 3 to 12 
species per plot with a mean of 8 species. From 61 species counted a wide variation in the number of individuals were shown that ranged from 1 individual of seven species to 98 individual of Croton macrostachyus Del. Furthermore the species-area curve showed an increase in species as the area of plot increases (Figure 3). This indicated that species richness and the area of plots are strongly positively correlated with $\mathrm{r}=1, \mathrm{p}<0.005$

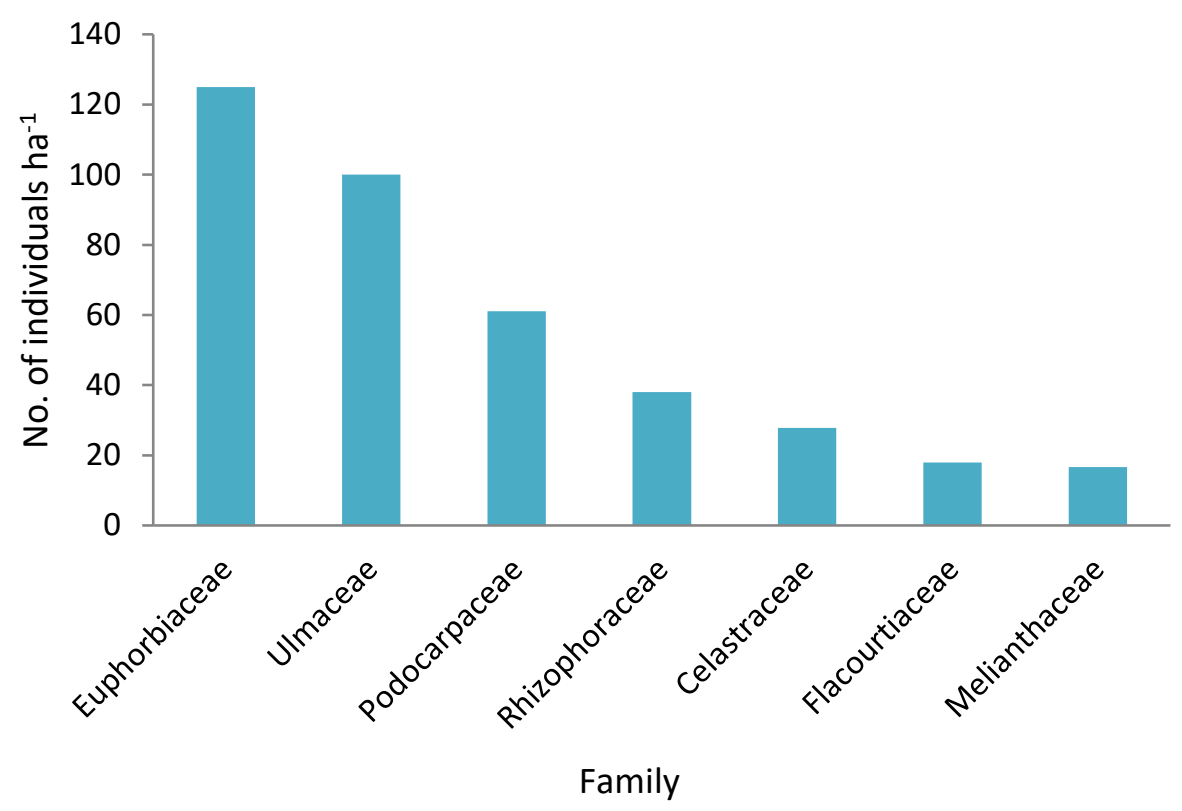

Figure 2. Species richness of dominant tree families in Munessa natural forest

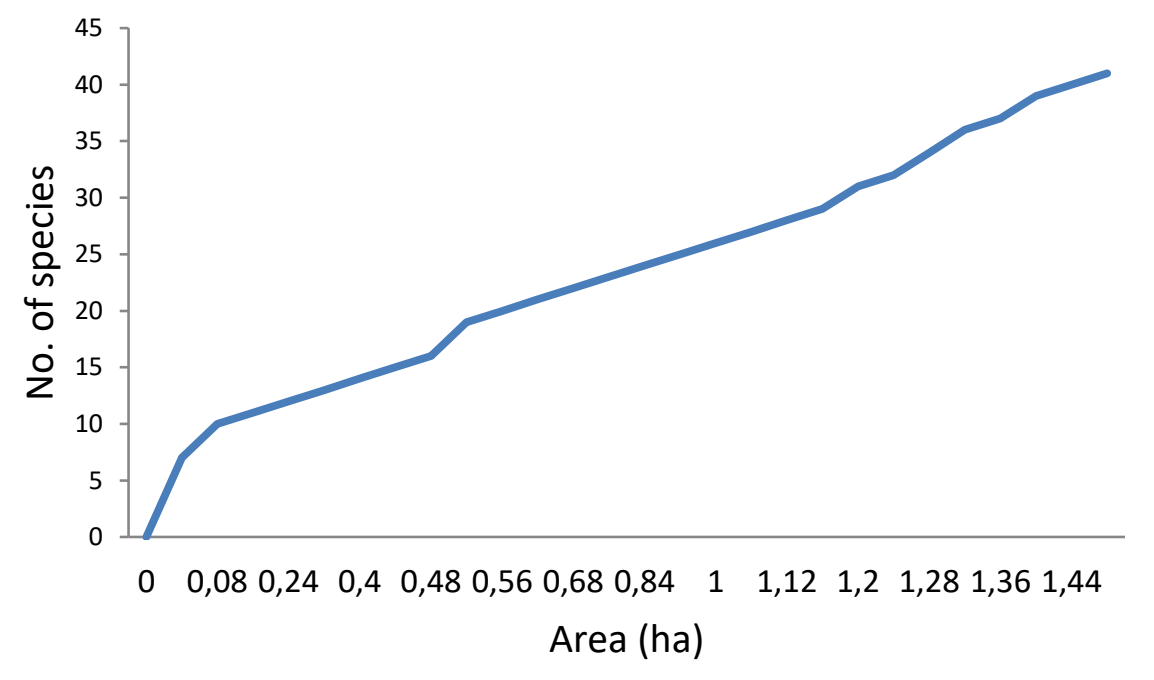

Figure 3. Species-area curve in Munessa natural forest 
Based on the criteria established by Krishnamurthy et al. (2010) species were grouped into five categories such as predominant, dominant, common, rare and very rare species considering their density (per 2 ha) (Table 1). Croton macrostachyus with 244 individuals and Celtis africana Burm.f with 200 individuals are classified as predominant tree species and represented $5 \%$ of species richness in the sample plot laid. This indicates $46 \%$ of the species density. On the other hand Podocarpus falcatus with 122 individuals are categorized into dominant species and it represented $2 \%$ of the species and $13 \%$ of the stand density in the sample plot laid. Four species such as Cassipourea malosana (Baker) Alston, Maytenus undata (Thunb.) Blackelock, Bersama abyssinica Fresen. and Dovyalis abysinica (A.Rich) Warb are classified as common species and accounted for $10 \%$ of the species richness. $21 \%$ of stand density represented this group. Twenty seven species including Allophylus abyssinicus (Hochst)Radlk, Ekebergia capensis Sparrm., and Prunus africana were under rare species category. They represented $66 \%$ of the species and $20 \%$ of stand density. Finally seven species including Apodytes dimdiata E. Mey. ex Arn, Calpurnia aurea and Dombiya torrid (J.F. Gmel.) P. Bampsare classified as very rare species and represented $17 \%$ of the species richness and $1 \%$ of tree density.

Table 1 . Group of species based on the criteria established by Krishnamurthy et al. (2010)

\begin{tabular}{ll} 
Category & No of Individuals \\
\hline Predominant species & $\geq 200$ \\
Dominant species & $100-199$ \\
Common species & $25-99$ \\
Rare species & $3-24$ \\
Very rare species & $<3$ \\
\hline
\end{tabular}

\section{Vegetation classification}

The vegetation classification at the 22 dissimilarity level from hierarchical cluster analysis resulted in four major tree species communities. Higher indicator value of a species was considered to name each community. The four community groups were Celtis africana - Croton macrostachyus, Croton macrostachyus - Celtis africana, Celtis africana - Podocarpus falcatus and Syzygium guineense - Croton macrostachyus (Table 2) and this are described as follows.

\section{CI: Celtis africana - Croton macrostachyus Community}

This community occurs in the altitudes between 2115 and $2159 \mathrm{~m}$ and comprises of 12 quadrates (about 0.49 ha). Two species, Celtis africana and Croton macrostachyus are found to be indicator species of the community as they display the highest indicator values. Some other tree species in the community includes Podocarpus falcatus, Bersama abyssinica, Millettia ferruginea (Hochst.) Bak. and Albizia grandibracteata Taub..

\section{CII: Croton macrostachyus - Celtis africana Community}

This community occurs between altitude ranges of 2169 and $2226 \mathrm{~m}$. The two indicator species of this community are Croton macrostachyus and Celtis africana comprising of 12 quadrates (0.49 ha). A sizeable number of tree species in the community include Podocarpus falcatus, Maytenus undata, Cassipourea malosana, and Ekebergia capensis. 


\section{CIII: Celtis africana - Podocarpus falcatus Community}

It occurs between 2208 and $2244 \mathrm{~m}$ altitude ranges. The two dominant species of this community are Celtis africana and Podocarpus falcatus and constitute of 11 quadrates (0.44 ha). It comprises of tree species including Croton macrostachyus, Cassipourea malosana, Pouteria adolfi-friedericii (Engl.) Baehni and Allophylus abyssinicus.

\section{IV: Syzygium guineense - Croton macrostachyus Community}

It occurs between altitudes ranges of 2246 and $2285 \mathrm{~m}$. Dominant species of this community are Syzygium guineense (Willd.) DC. and Croton macrostachyus and it comprises of 19 quadrates (0.76 ha). Some of the tree species includes Celtis africana, Podocarpus falcatus, Cassipourea malosana and Allophylus abyssinicus.

Table 2. Synoptic cover abundance value for species reaching $>2 \%(\mathrm{CI}=$ Community type $1, \mathrm{CII}=$ Community type $2, \mathrm{CIII}=$ Community type 3 , and CIV = Community type 4)

\begin{tabular}{lllll}
\hline Species & $\mathrm{CI}$ & $\mathrm{CII}$ & $\mathrm{CIII}$ & $\mathrm{CIV}$ \\
\hline Albizia grandibracteata & 3.8 & 0.0 & 0.0 & 0.0 \\
Allophylus abyssinicus & 0.0 & 0.0 & 2.8 & 2.0 \\
Bersama abyssinica & 5.7 & 3.7 & 4.6 & 2.0 \\
Cassipourea malosana & 5.7 & 5.2 & 12.7 & 6.4 \\
Celtis africana & $\mathbf{3 5 . 7}$ & $\mathbf{2 1 . 5}$ & $\mathbf{2 6 . 3}$ & 11.6 \\
Croton macrostachyus & $\mathbf{2 4 . 4}$ & $\mathbf{3 9 . 2}$ & 18.1 & $\mathbf{1 7 . 2}$ \\
Ekebergia capensis & 2.0 & 3.0 & 0.0 & 0.0 \\
Fagaropsis angolensis & 2.0 & 0.0 & 0.0 & 0.0 \\
Ficus sycomorus & 0.0 & 2.0 & 0.0 & 0.0 \\
Galiniera saxifraga & 0.0 & 0.0 & 2.8 & 0.0 \\
Maytenus undata & 2.0 & 6.7 & 3.7 & 6.0 \\
Millettia ferruginea & 5.6 & 0.0 & 0.0 & 0.0 \\
Podocarpus falcatus & 9.5 & 13.3 & $\mathbf{2 1 . 8}$ & 7.1 \\
Pouteria adolfi-friedericii & 0.0 & 0.0 & 3.6 & 0.0 \\
Psydrax schimperiana & 0.0 & 0.0 & 2.1 & 0.0 \\
Syzygium guineense & 0.0 & 0.0 & 0.0 & $\mathbf{3 8 . 9}$ \\
Teclea simplicifolia & 0.0 & 2.0 & 0.0 & 0.0 \\
Vitex doniana & 3.8 & 0.0 & 0.0 & 0.0 \\
\hline & & & & \\
\hline
\end{tabular}




\section{Species richness, diversity and evenness in the communities}

The overall Shannon diversity index of Munessa natural forest was 2.6, which is lower than other evergreen afromontane forests in Ethiopia such as Zege forest (Alelign et al., 2007), Tara Gedam and Abebaye forests (Zegeye et al., 2011) and Zengena forest (Tadele et al., 2014) but it is higher than Menagesha Suba forest (Beche, 2011) and Kuandisha forest (Berhanu et al., 2016) (Table 3). This low diversity index in the study area is associated with high disturbance. The species evenness of the study area was 0.39 that was much lesser than 1 indicating uneven distribution of individuals within a species. This is due to the fact that anthropogenic impact, particularly free grazing and selective tree cutting, impairs the growth and survival rate of individuals of a species.

Table 3. Shannon diversity index of Munessa natural forest compared to other forests in Ethiopia

\begin{tabular}{lcl}
\hline Forest Name & Shannon-Wiener index & Authors \\
\hline Zege & 3.72 & Alelign et al., 2007 \\
Tara Gedam and Abebaye & 2.98 & Zegeye et al., 2011 \\
Zengena & 2.74 & Tadele et al., 2014 \\
Munesa & 2.6 & Present study \\
Menagesha Suba & 2.57 & Beche, 2011 \\
Kuandisha & 2.5 & Berhanu et al., 2016 \\
\hline
\end{tabular}

The value of Shannon diversity index and species evenness is mainly affected by both the number of species and the number of stands in the community. Shannon diversity index is higher when the number of species and stands are higher as well as when the number of stands is evenly distributed. But species evenness is higher when the number of species is higher and the number of stands is evenly distributed throughout the species in the communities. Therefor the result of this study revealed that the species richness and Shannon diversity index in the communities is strongly positively correlated $(r=0.92, p<$ 0.005); the richer the species in the community is, the more diverse it becomes in that community. On the other hand, the correlation between Shannon diversity index and species evenness is negatively correlated $(r=-0.10, p<0.005)$; the more diverse a community is, the less evenly it is the distribution in that community (Table 4). The findings are not in line with reports elsewhere that suggest positive and strong correlations among species richness, diversity and evenness (Stirling and Wilsey, 2001). That is due to the reason behind the number of stands in the species are unevenly distributed while some species like Croton macrostachyus and Celtis africana shown higher number of individuals than other species in the communities and that may lead for the higher values of diversity. In terms of habitat, as it is shown in Table 4, community IV consisted of the highest species richness and diversity than other communities. Unlikely community II contained the highest evenness value than others.

\section{Similarity of species composition among the communities}

The computed Sorensen's similarity coefficient of the three communities displayed community II and III share more species in common (44\%) followed by community III and IV (41\%), community I and III 
(40\%), community II and IV (39\%), community I and IV (38\%) and that of community I and II (35\%) (Table 5).

Table 4. Species richness, Diversity and Evenness of the plant communities in Munessa natural forest

\begin{tabular}{llllll}
\hline Communities & Altitude $(\mathrm{m})$ & $\begin{array}{l}\text { Species } \\
\text { Richness }\end{array}$ & $\begin{array}{l}\text { Diversity Index } \\
\left(\mathrm{H}^{\prime}\right)\end{array}$ & Hmax & $\begin{array}{l}\text { Evenness } \\
\left(\mathrm{H}^{\prime} \mathrm{E}\right)\end{array}$ \\
\hline I & 2137 & 11 & 1.89 & 2.40 & 0.79 \\
II & 2198 & 15 & 1.87 & 2.71 & 0.69 \\
III & 2226 & 13 & 2.01 & 2.56 & 0.78 \\
IV & 2266 & 25 & 2.36 & 3.22 & 0.73 \\
\hline
\end{tabular}

Table 5. Similarity index of tree species composition in three communities

\begin{tabular}{lllll}
\hline Community Types & I & II & III & IV \\
\hline I & - & 0.35 & 0.4 & 0.38 \\
II & - & - & 0.44 & 0.39 \\
III & - & - & - & 0.41 \\
IV & - & - & - & - \\
\hline
\end{tabular}

Vegetation structure

Tree density

The total density of individual trees of the natural forest of Munessa with DBH $>5$ were 481 individuals per ha (Table 6). These density is lower compared to some other Afromontane forests in Ethiopia, such as, Kimphee forest (3059 stems per ha) (Senbeta and Teketay, 2003), Masha Anderacha forest (1709 stems per ha) (Yeshitela and Bekele, 2003), and Dindin forest (1750 stems per ha) (Shibru and Balcha, 2004). This could be due to variations in landscape topographic gradients as well as habitat qualities linked to ecological requirements of component tree species in the respective forests. Only two species had more or equals to 100 trees per ha. Croton macrostachyus had the highest density with 122 trees per ha followed by Celtis africana with 100 trees per ha, Podocarpus falcatus with 61 trees per ha, and Maytenus undata with 28 trees per ha. $95 \%$ of the tree species, which were about 39 species, had a density of less than 100 stems per ha. The density of tree species with DBH greater than $20 \mathrm{~cm}$ was 356 trees per ha which accounts for $74 \%$ of the total tree density. The corresponding tree density with DBH greater than $30 \mathrm{~cm}$ was 240 trees per ha which accounts for $50 \%$ of the total tree density. The ratio of the overall density of tree species with DBH greater than $20 \mathrm{~cm}$ to those greater than $30 \mathrm{~cm}$ was 1.48 . It indicated that the natural forest of Munessa was dominated by small sized trees. This predominance of small-sized trees was largely due to the high density of Croton macrostachyus and Maytenus undata. The major reason was due to selective cutting of medium and high sized trees for fire wood, local houses construction and furniture making. Similar conditions were reported from Dindin forest where Olinia rochetiana A.Juss. and Myrsine africana were dominant (Shibru and Balcha, 2004); and in MashaAnderacha forest where Cyathea manniana Hook. was dominant (Yeshitela and Bekele, 2003). 
Table 6. Density of tree species and their percentage coverage according to DBH class

\begin{tabular}{lcc}
\hline & & \\
DBH Class $(\mathrm{cm})$ & Density $\left(\mathrm{ha}^{-1}\right)$ & Percentage $(\%)$ \\
\hline & & \\
$7-20$ & 162 & 33.72 \\
$21-30$ & 102 & 21.16 \\
$31-40$ & 76 & 15.81 \\
$41-50$ & 45 & 9.3 \\
$51-60$ & 36 & 7.44 \\
$61-80$ & 29 & 6.05 \\
$>=81$ & 31 & 6.51 \\
\hline & & \\
Total & 481 & 100 \\
\hline
\end{tabular}

\section{Frequency}

The frequency of tree species with DBH $>=5 \mathrm{~cm}$ in the natural forest of Munessa ranged from 3 to $97 \%$. About $80 \%$ of tree species belonging to frequency class A were absent in most of the plots laid (Figure 4). In contrast, tree species such as Podocarpus falcatus, Croton macrostachyus, and Celtis africana were most frequently appeared in many of the sample plots laid and they were belonging to frequency class $\mathrm{E}$. From the figure it was depicted that high number of species were found in lower frequency classes and low number of species were found in higher frequency classes. This pattern shows the heterogeneity of tree species in the study area that implies uneven distribution of tree species in the natural forest of Munessa. The relative frequency of the species was ranged from 0.42 to $14.71 \%$. The highest relative frequency was documented for Croton macrostachyus with $14.71 \%$, followed by Podocarpus falcatus and Celtis africana with $13.45 \%$ each. Generally, $7 \%$ of the species had relative frequency above 10, 32 $\%$ of the species was between 1 and 10 , and $61 \%$ was below $1 \%$.

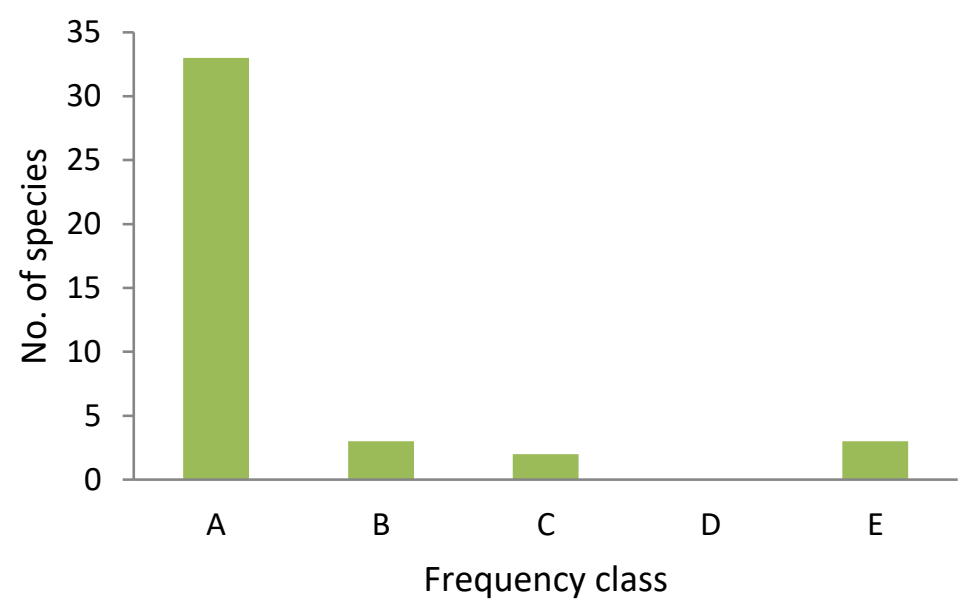

Figure 4. Number of species in each frequency class (A: 1-20\%, B: 21-40\%, C: 41-60\%, D: 61-80 $\%$, E: $81-100 \%)$ 


\section{Diameter and height class distribution}

A total of 693 individuals of tree species whose $\mathrm{DBH}$ and height $>=7 \mathrm{~cm}$ and $>=2 \mathrm{~m}$ respectively were recorded from Munessa natural forest. DBH was classified into seven classes of $10 \mathrm{~cm}$ intervals (Class 1=7-20, Class 2=21-30, Class 3=31-40, Class $4=41-50$, Class $5=51-60$, Class $6=61-80$, Class $7>=81$ ) (Figure 5). Conversely, the height of trees was classified into nine classes of $5 \mathrm{~m}$ intervals (Class $1=2-5$ $\mathrm{m}$, Class 2= 6-10 m, Class 3=11-15 m, Class 4=16-20 m, Class 5=21-25 m, Class 6=26-30 m, Class 7= $31-35 \mathrm{~m}$, Class $8=36-40 \mathrm{~m}$, Class $9>=41 \mathrm{~m}$ ) (Figure 6). The general pattern of tree distribution along DBH classes depicted an inverted J-shaped. These patterns of population distribution indicated a healthy regeneration status of the forests (Teketay, 1997). Similar results were reported for Kimphee forest (Senbeta and Teketay, 2003), Denkoro forest (Ayalew et al., 2006), Chato natural forest (Abdena, 2010) and Wof Washa natural forest (Fisaha et al., 2013). Podocurpus falcatus shows the highest DBH with 238 $\mathrm{cm}$ and Celtis africana shows the lowest DBH with $7.64 \mathrm{~cm}$.

High density of tree species was concentrated in the first DBH class of the measured value i.e., from 7-20 $\mathrm{cm}$ and the lowest tree density was within the six DBH class i.e., from $61-80 \mathrm{~cm}$. It was consistently declined from the lower DBH class to the higher DBH class except the $7^{\text {th }}$ class in which slight increment of individuals was seen. This pattern indicates that the majority of tree species had the highest number of individuals in lower DBH class which in turn shows the forest vegetation has good reproduction and recruitment potential. The distribution of tree species density with respect to height class was inclined and decline alternatively. This indicated that the height class distribution of the study area shows an irregular pattern. The second height class shows the highest tree density i.e., from 6-10 m and the lowest tree density was within the seventh class i.e., from 31-35 m. Podocarpus falcatus was the highest tree species in height reaching $65 \mathrm{~m}$.

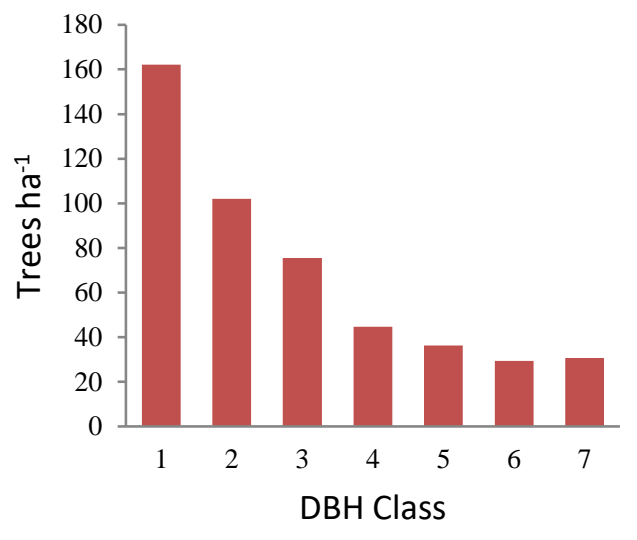

Figure 5. Distribution of tree density along DBH class

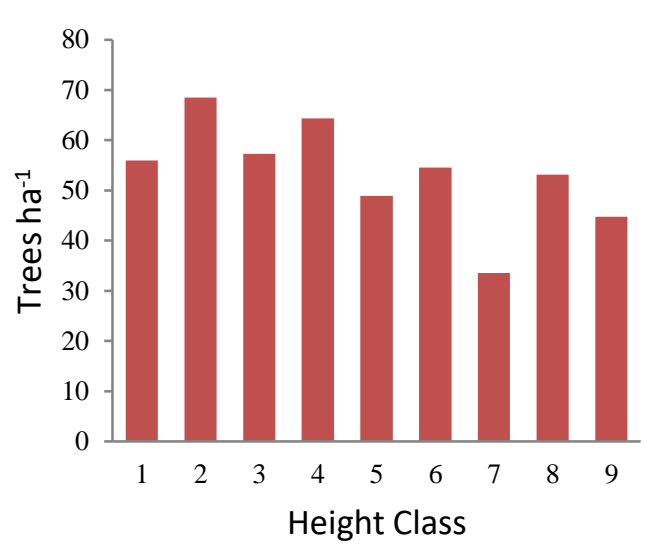

Figure 6. Distribution of tree density along height class

\section{Basal area}

Basal area (BA) is an important parameter for measuring relative importance of tree species in a forest (Bekele, 1994) than stem counts (Cain and Castro, 1960). Hence, plant species with larger basal area in a 
forest is considered as the most important species in that forest. The sum total BA of tree species with $\mathrm{DBH}>=5 \mathrm{~cm}$ was $91.75 \mathrm{~m}^{2}$ per ha. Eight species were contributed for $93 \%$ of BA in the study area. Podocarpus falcatus was the most important tree species of the forest with BA of $40.51 \mathrm{~m}^{2}$ per ha which is about $44.15 \%$. The second most important tree species was Celtis africana with BA of $16.02 \mathrm{~m}^{2}$ per ha which is $17.46 \%$. Others plant species were Croton macrostachyus with 15.08, Pouteria adolfi-friedericii with 5.35, Ekebergia capensis with 2.97, and Bersama abyssinica with 1.82, Vitex doniana with 1.60, Cassipourea malosana with $1.21 \mathrm{BA}$ in $\mathrm{m}^{2}$ per ha (Table 7). Calpurnia aurea contributed the least amount of BA, about $0.01 \mathrm{~m}^{2}$ per ha, to the natural forest of Munessa.

Table 7. BA and relative BA of tree species in Munessa natural forest

\begin{tabular}{lcc}
\hline Species & $\mathrm{BA}\left(\mathrm{m}^{2} \mathrm{ha}^{-1}\right)$ & Relative BA (\%) \\
\hline Podocarpus falcatus & 40.51 & 44.15 \\
Celtis africana & 16.02 & 17.46 \\
Croton macrostachyus & 15.08 & 16.44 \\
Pouteria adolfi-friedericii & 5.35 & 5.83 \\
Ekebergia capensis & 2.97 & 3.24 \\
Bersama abyssinica & 1.82 & 1.99 \\
Vitex doniana & 1.60 & 1.74 \\
Cassipourea malosana & 1.21 & 1.32 \\
\hline
\end{tabular}

From the total BA of twelve forests in Ethiopia, four of them, that are Menagesha Suba $\left(158.68 \mathrm{~m}^{2}\right.$ per ha), Dodola (129 $\mathrm{m}^{2}$ per ha), Kimphe Lafa (114.4 $\mathrm{m}^{2}$ per ha) and Menna Angetu (94.22 $\mathrm{m}^{2}$ per ha) shows the highest value than Munessa natural forest $\left(91.75 \mathrm{~m}^{2}\right.$ per ha) and all the rest forests selected for comparison shows lower value. This is due to the presence of relatively larger DBH sized tree species in the study area (Table 8).

\section{Importance value index (IVI)}

The relative ecological significance and/or dominance of tree species in a forest ecosystem could best be unconcealed from the analysis of IVI values (Curtis and Mcintosh, 1950). The result from our analysis enabled us to identify the dominant tree species in Munessa natural forest. The IVI of tree species was ranged from 0.62 to 70.29 . Three species depicted the IVI value of 20 and above. Podocarpus falcatus was relatively the dominant tree species with IVI value of 70.29, followed by Croton macrostachyus with 56.53, Celtis africana with 51.67 and Maytenus undata with 14.98 (Table 9). The first three species contributed $60 \%$ of the IVI value and the rest $40 \%$ was contributed by 38 species that had the IVI value less than 20. Calpurnia aurea contributed the least amount of IVI, about 0.62, in the Munessa natural forest. 
Table 8. Comparison of BA of Munessa natural forest with other forests in Ethiopia in $\mathrm{m}^{2}$ per ha

\begin{tabular}{|c|c|c|}
\hline Forest Name & Basal Area (m² per ha) & Authors \\
\hline Menagesha Suba & 158.68 & Beche, 2011 \\
\hline Dodola & 129 & Hundera, 2007 \\
\hline Kimphe Lafa & 114.4 & Aliyi et al., 2015 \\
\hline Menna Angetu & 94.22 & Lulekal et al., 2008 \\
\hline Munesa & 91.75 & Present study \\
\hline Menagesha Amba Mariam & 84.17 & Tilahun, 2009 \\
\hline Masha Anderacha & 81.9 & Yeshitela and Bekele, 2003 \\
\hline Bibita & 69.9 & Denu, 2007 \\
\hline Magada & 68.52 & Bekele, 2005 \\
\hline Wof-Washa & 64.32 & Fisaha et al., 2013 \\
\hline Dindin & 49 & Shibiru and Balcha, 2004 \\
\hline Denkoro & 45 & Ayalew et al., 2006 \\
\hline Senka Meda & 34.7 & Bantiwalu, 2010 \\
\hline
\end{tabular}

Table 9. IVI of top 10 tree species with their corresponding Relative Dominance (Rdo), Relative Frequency (Rfr), and Relative Density (Rde) in Munessa natural forest

\begin{tabular}{|c|c|c|c|c|c|}
\hline Species & Family & $\mathrm{R}_{\mathrm{do}}(\%)$ & $\mathrm{R}_{\mathrm{fr}}(\%)$ & $\mathrm{R}_{\mathrm{de}}(\%)$ & IVI \\
\hline Podocarpus falcatus & Podocarpaceae & 44.15 & 13.45 & 12.69 & 70.29 \\
\hline Croton macrostachyus & Euphorbiaceae & 16.44 & 14.71 & 25.38 & 56.53 \\
\hline Celtis africana & Ulmaceae & 17.46 & 13.45 & 20.77 & 51.67 \\
\hline Maytenus undata & Celastraceae & 0.80 & 8.40 & 5.77 & 14.98 \\
\hline Cassipourea malosana & Rhizophoraceae & 1.32 & 5.04 & 7.88 & 14.25 \\
\hline Bersama abyssinica & Melianthaceae & 1.99 & 6.72 & 3.46 & 12.17 \\
\hline Ekebergia capensis & Meliaceae & 3.24 & 2.94 & 1.54 & 7.72 \\
\hline Pouteria adolfifriedericii & Sapotaceae & 5.83 & 0.42 & 0.19 & 6.44 \\
\hline Allophylus abyssinicus & Sapindaceae & 0.61 & 3.78 & 1.54 & 5.93 \\
\hline Aningeria adolfi-friedericii & Sapotaceae & 0.67 & 2.10 & 1.54 & 4.31 \\
\hline
\end{tabular}

The dominance of five species, such as Podocarpus falcatus, Croton macrostachyus, Celtis africana, Maytenus undata and Cassipourea malosana together contributed $73 \%$ of the total stand density, $55 \%$ of 
frequency, $80 \%$ of total basal area and $69 \%$ of IVI, indicates that these species utilize the majority of forest space and resources in the study area. Of these five dominant species, Podocarpus falcatus is belongs to the Podocarpaceae family, Croton macrostachyus to the Euphorbiaceae, Celtis africana to the Ulmaceae, Cassipourea malosana to the Rhizophoraceae, and Maytenus undata to the Celastraceae.

\section{Forest structure}

The analysis of forest structures and examination of its patterns provide an estimate of the regeneration and recruitment status of tree species as well as to verify the viability status of the population that could further be employed for devising evidence based conservation and management strategies (Teketay, 2005a, Abiyu et al., 2006). Various patterns of population structures have been reported for different species in other Afromontane forests of the country by many authors including Teketay (2005a), Alelign et al. (2007), Yineger et al. (2008), Bantiwalu (2010), Beche (2011), Tadele et al. (2014) and Berhanu et al. (2015). In this study, the six tree species structure was determined considering their density at various DBH classes. As a result, four species population patterns were recognized (Figure 7). The first pattern is an inverted J-shape, which indicates the presence of large number of individuals at lower DBH classes with a gradual decreasing trend toward higher DBH classes. A few species including Croton macrostachyus had shown this patter, suggests good recruitment and regeneration. Similar pattern was reported by Teketay (1997) for 17 species at Gara Ades and 18 species at Menagesha dry Afromontane forests. The second pattern indicates the presence of abundant individuals at lower DBH classes and the absence of individuals at intermediate and higher DBH classes. Some species such as Cassipourea malosana and Maytenus undat were in this category. This pattern indicated heavy human pressure on higher DBH classes that leading to scarcity of mature individuals that can serve as seed sources. The third pattern revealed the presence of large number of individuals at the lower and higher DBH classes and the absence of individuals at the intermediate DBH classes. Some species such as Podocarpus falcatus and Bersama abyssinica had shown this patter. Similar results were reported by Teketay (2005a) in agreement with the second and third population patterns. The fourth pattern depicted the presence of large number of individuals at the intermediate DBH classes and small number of individuals at the lower and higher DBH classes. A few species including Celtis africana exhibited this patter. This pattern shows hampered regeneration, which could be attributed to poor recruitment coupled with selective cutting of individuals in the higher DBH classes. Feyera Senbeta and Demel Teketay (2003) reported similar population patterns in Kimphee forest.

\section{Regeneration status}

The total density of seedling, sapling and mature tree in Munessa natural forest was 6,934, 1,686, and 481 individuals per ha respectively (Figure 8). The density of seedlings obtained from the study area was less than the report made for Wof-Washa by Fisaha et al. (2013) and Kuandisha by Birhanu et al. (2016) which was $8,796.5$ and 26,259 individuals per ha respectively. This could be due to the high exposure of the forest for grazing and other human impacts such as tree cutting for firewood, house construction and timber production. The density of seedlings and saplings was greater than mature trees. Conversely, the ratio of seedling to sapling was 4.11, seedling to mature tree was 14.4 and sapling to mature tree was 3.5. This result shows that the distribution of seedlings is much greater than saplings and mature trees and that of saplings is greater than mature trees. Accordingly, the number of seedlings and saplings being regenerated in the forest is about eighteen fold of the mature trees. Therefore, it is possible to say that the regeneration potential of the forest is relatively higher and its future floristic composition and diversity 

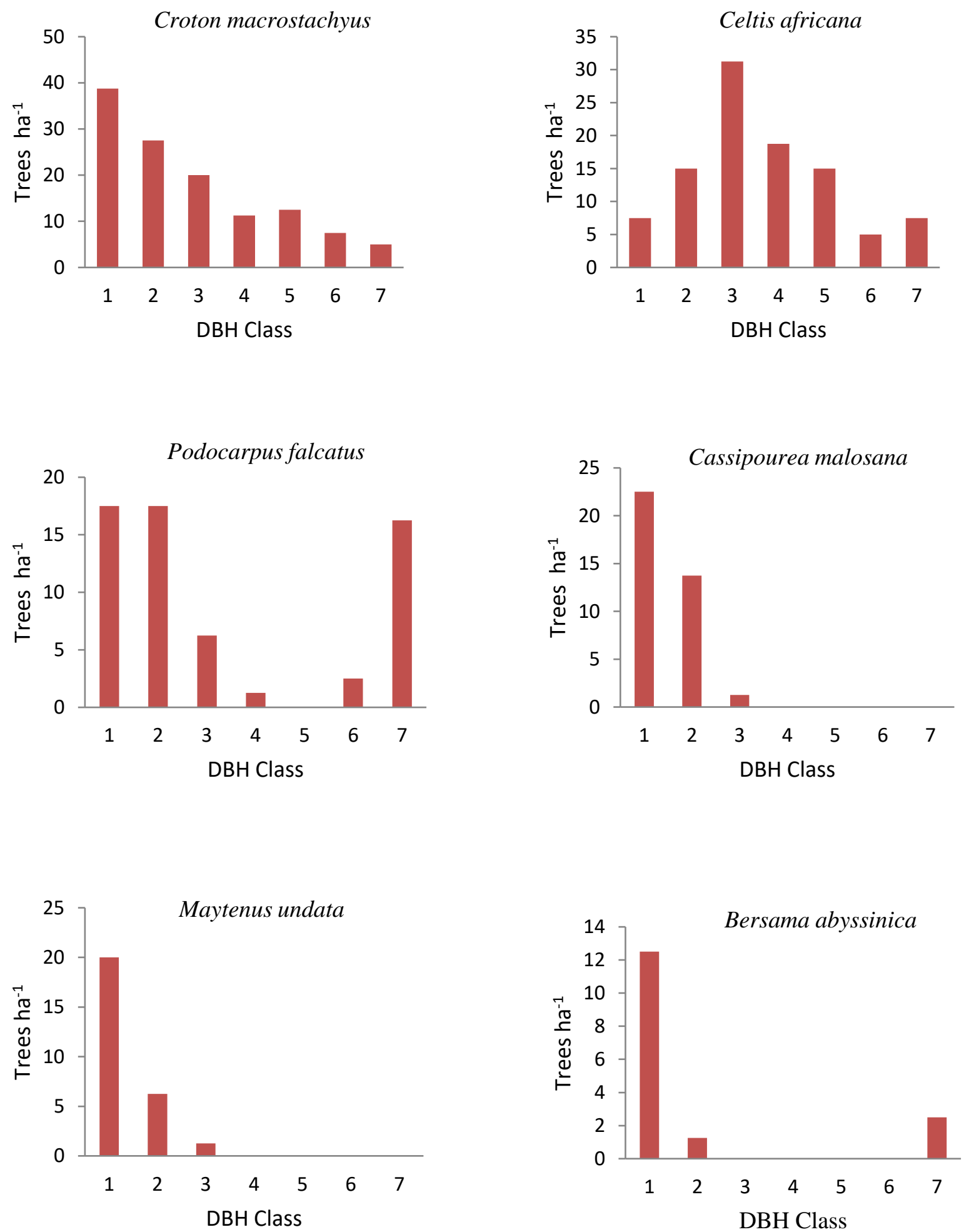

Figure 7. Population structure of representative tree species in DBH class $(\mathrm{cm})$ 
will be much better compared to the current situation. Seedling density was varied among species that ranges from 7 individuals per ha for Erythrococca abyssinica to 1826 individuals per ha for Cassipourea malosana. Generally, in the present study $71 \%$ of the species had seedlings, whereas $29 \%$ of the species lacked seedlings including Albizia grandibracteata, Ficus sycomorus, Galiniera saxifrage and Hypericum revolutum.

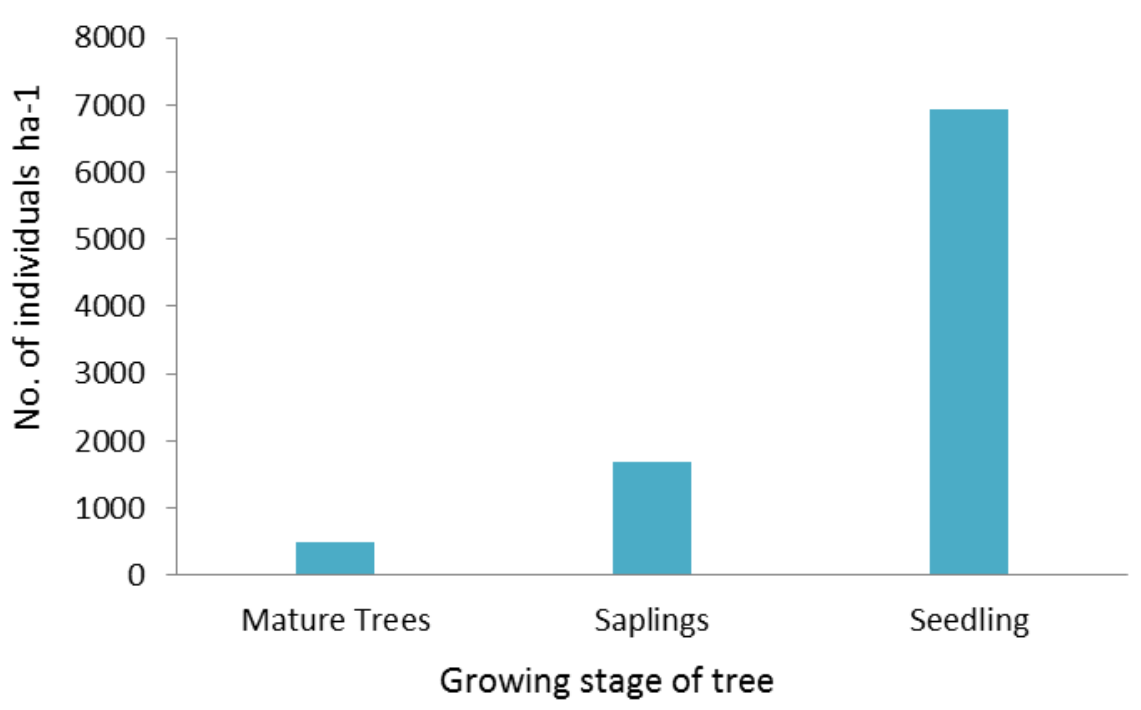

Figure 8. Density of seedlings, saplings and mature trees in Munessa natural forest

\section{Levels of disturbance and species prioritization}

Disturbances in the natural forests may include wind throw, natural and manmade fires, landslides, grazing, tree felling and clearing for cultivation (Teketay, 2005b). In the present study, free grazing and selective cutting of trees were the most disturbance factors observed during the assessment. Most commonly the species richness of trees and seedling density are negatively correlated with disturbance Økland (1990). Dead stumps, in the form of fallen and uprooted trees and standing dead trees were observed in most sample plots laid. This shows the severity of anthropogenic disturbance in the study area. Dead stumps of 14 species and dead standing trees of 11 species were recorded. Croton macrostachyus was the most disturbed tree species that were accounted for $18 \%$ of disturbance followed by Maytenus undata, Allophylus abyssinicus, Bersama abyssinica, Podocarpus falcatus, Prunus Africana and Calpurnia aurea. Some characteristic species of the dry evergreen afromontane forest such as Juniperus procera were absent in the natural forest of Munesa. Regardless of the wide distributional range of Juniperus procera elsewhere in Ethiopia at altitudes 1500-3000 m a.s.l (Hedberg et al., 2009), the species is naturally absent in the study area. Seed predation has been noted to play its own role in reducing the seedling population of woody species such as Juniperus procera in the dry evergreen afromontane forests of Ethiopia (Teketay, 2005b). Species with lower IVI value were usually prioritized for conservation. Generally, 8 tree species with IVI value less than 2 were identified and received top priority status for conservation and management interventions in this study. Those tree species includes Apodytes dimdiata, Calpurnia aurea, Dombiya torrida, Fagaropsis angolensis, Hypericum revolutum, Maesa lanceolata, Nuxia congesta, and Ochna holstii. 


\section{CONCLUSION AND RECOMMENDATION}

This study revealed that Munessa natural forest is more diverse in tree species compared to Menagesha Suba and Kuandisha forest. But it is less diverse compared with other afromontane forests such as Zege, Tara Gedam and Abebaye, and Zengena forest. This is due to the relatively higher disturbance level from grazing and selective logging by the local community. As a result, a significant number of woody species were either not regenerating or selectively removed for various purposes. For instance, even though the total BA of tree species was higher, the proportion of individuals with DBH was very high in lower DBH class compared with higher DBH class. Tree species richness generally showed an alternative decreasing and increasing trends from lower to higher elevations. Some species such as Juniperus procera, Hagenia abyssinica and Olea europaea subsp. cuspidate, which are characteristic species in the afromontane forests of Ethiopia, are naturally absent in the natural forest of Munessa.

Thus, we recommend conservation and management actions are mandatory for the priority species that shows low IVI and the entire forest as well. We suggest that free grazing and selective cutting of tree inside the forest should be abandoned. Moreover, bare land in the forest should be planted with prioritized species. The cut and carry system of grass from grazing areas can be another viable option to reduce the pressure from the forest. An investigation on soil seed banks should be conducted and receive top priority so that additional management interventions can be forwarded.

\section{Acknowledgments}

The Authors would like to thank both Arsi University and Addis Ababa University for funding this research and Oromia Forest and Wildlife Enterprise for giving permission to conduct this study on site.

\section{References}

Abate Ayalew (2003). Floristic Composition And Structural Analysis Of The Denkoro Forest. (Unpublished Msc Thesis), Addis Ababa University.

Abdena, F. 2010. Floristic Composition And Structure Of Chato Natural Forest In Horo Guduru Wollega Zone Of Oromia Region, West Ethiopia. Ph. D. Thesis.

Abebe, G. T. 2008. Ecology Of Regeneration And Phenology Of Seven Indigenous Tree Species In A Dry Tropical Afromontane Forest, Southern Ethiopia. Addis Ababa: Addis Ababa University.

Abiyu, A., Vacik, H. \& Glatzel, G. 2006. Population Viability Risk Management Applied Boswellia Papyrifera (Del.) Hochst In North-Eastern Ethiopia. Journal Of The Drylands, 1, 98-107.

Admassu, A., Teshome, S., Ensermu, K., Abyot, D. \& Alemayhu, K. 2016. Floristic Composition And Plant Community Types Of Agama Forest, An Afromontane Forest In Southwest Ethiopia. Journal Of Ecology And The Natural Environment, 8, 55-69.

Alelign, E., Teketay, D., Yemshaw, Y. \& Edwards, S. 2007. Diversity And Status Of Regeneration Of Woody Plants On The Peninsula Of Zegie, Northwestern Ethiopia. Tropical Ecology, 48, 37.

Ayalew, A., Bekele, T. \& Demissew, S. 2006. The Undifferentiated Afromontane Forest Of Denkoro In The Central Highland Of Ethiopia: A Floristic And Structural Analysis. Sinet: Ethiopian Journal Of Science, 29, 45-56.

Beche, D. 2011. Floristic Composition, Diversity And Structure Of Woody Plant Species In Menagesha Suba State Forest, Central Ethiopia. Msc. Thesis. Addis Ababa University, Addis Ababa.

Bekele, T. 1994. Phytosociology And Ecology Of A Humid Afromontane Forest On The Central Plateau Of Ethiopia. Journal Of Vegetation Science, 5, 87-98.

Berhanu, A., Woldu, Z. \& Demissew, S. 2016. Elevation Patterns Of Woody Taxa Richness In The Evergreen Afromontane Vegetation Of Ethiopia. Journal Of Forestry Research, 28, 787-793.

Curtis, J. T. \& Mcintosh, R. P. 1950. The Interrelations Of Certain Analytic And Synthetic Phytosociological Characters. Ecology, 31, 434-455.

Danoff-Burg, J. \& Xu, C. 2008. Measuring Biological Diversity.

Devi, L.S. And Yadava, P. (2006) Floristic Diversity Assessment And Vegetation Analysis Of Tropical Semievergreen Forest Of Manipur, North East India. Tropical Ecology 47(1), 89-98.

Dhaulkhandi, M., Dobhal, A., Bhatt, S. \& Kumar, M. 2008. Community Structure And Regeneration Potential Of Natural Forest Site In Gangotri, India. Journal Of Basic And Applied Sciences, 4, 49-52. 
Didita, M., Nemomissa, S. \& Gole, T. W. 2010. Floristic And Structural Analysis Of The Woodland Vegetation Around Dello Menna, Southeast Ethiopia. Journal Of Forestry Research, 21, 395-408.

Duriaux, J.-Y. \& Baudron, F. 2016. Understanding People And Forest Interrelations Along An Intensification Gradient In Arsi-Negele, Ethiopia, Agrarian Change In Tropical Landscapes. Center For International Forestry

Edwards S, Demissew S, Tadesse M, Hedberg I (1995) Flora Of Ethiopia And Eritrea (Vol. 2:1): Magnoliaceae To Flacourtiaceae. The National Herbarium, Addis Ababa, Pp 1-532

Edwards S, Demissew S, Hedberg I (1997) Flora Of Ethiopia And Eritrea (Vol. 6): Hydrocharitaceae To Arecaceae. The National Herbarium, Addis Ababa, Pp 1-586

Fisaha, G., Hundera, K. \& Dalle, G. 2013. Woody Plants' Diversity, Structural Analysis And Regeneration Status Of Wof Washa Natural Forest, North-East Ethiopia. African Journal Of Ecology, 51, 599-608.

Friis, I. \& Lawesson, J. 1993. Altitudinal Zonation In The Forest Tree Flora Of North East Tropical Africa. Opera Botanica, 121, 125-128.

Fritzsche, F., Zech, W. \& Guggenberger, G. 2007. Soils Of The Main Ethiopian Rift Valley Escarpment: A Transect Study. Catena, 70, 209-219.

Glowka, L., Burhenne-Guilmin, F. \& Synge, H. 1994. Guide To The Convention On Biological Diversity, Iucn--The World Conservation Union. Hedberg I, Edwards S, Nemomissa S. 2003. Flora Of Ethiopia And Eritrea (Vol 4-1): Apiaceae To Dipsacaceae. Addis Ababa And Uppsala: The National Herbarium, P. 1-352

Hedberg I, Kelbessa E, Edwards S, Demissew S, Persson E (2006) Flora Of Ethiopia And Eritrea (Vol. 5): Gentianaceae To Cyclocheilaceae. The National Herbarium, Addis Ababa, Pp 1-690

Hedberg I, Friis I, Persson E (2009a) Flora Of Ethiopia And Eritrea (Vol. 1): Lycopodiaceae To Pinaceae. The National Herbarium, Addis Ababa, Pp 1-305

Ibc 2009. Convention On Biological Diversity (Cbd) Ethiopia's 4th Country Report. Institute Of Biodiversity Conservation: Addis Ababa, Ethiopia.

Jost, L. 2007. Partitioning Diversity Into Independent Alpha And Beta Components. Ecology, 88, 2427-2439.

Kelbessa, E. \& Demissew, S. 2014. Diversity Of Vascular Plant Taxa Of The Flora Of Ethiopia And Eritrea. Ethiopian Journal Of Biological Sciences, 13, 37-45.

Krebs Cj (1999) Ecological Methodology. Addison Wiseley Longman, New York, Pp 1-694

Lamprecht, H. 1989. Silviculture In The Tropics: Tropical Forest Ecosystems And Their Tree Species: Possibilities And Methods For Their Long-Term Utilization, Eschborn, De: Gtz.

Maguran Ae (1988) Ecological Diversity And Its Measurement. Princeton University Press, Princeton, Pp 1-177

Mccune, B., Grace, J. B. \& Urban, D. L. 2002. Analysis Of Ecological Communities, Mjm Software Design Gleneden Beach, Or.

Oksanen, J., Blanchet, F., Friendly, M., Kindt, R., Legendre, P., Mcglinn, D., Minchin, P., O'hara, R., Simpson, G. \& Solymos, P. 2016. Vegan: Community Ecology Package. R Package Version 2.4-1. 2016. There Is No Corresponding Record For This Reference.

Paritsis, J. \& Aizen, M. A. 2008. Effects Of Exotic Conifer Plantations On The Biodiversity Of Understory Plants, Epigeal Beetles And Birds In Nothofagus Dombeyi Forests. Forest Ecology And Management, 255, 15751583.

Senbeta, F. \& Teketay, D. 2003. Diversity, Community Types And Population Structure Of Woody Plants In Kimphee Forest, A Unique Nature Reserve In Southern Ethiopia. Ethiopian Journal Of Biological Sciences, 2, 169-187.

Shibru, S. \& Balcha, G. 2004. Composition, Structure And Regeneration Status Of Woody Species In Dindin Natural Forest, Southeast Ethiopia: An Implication For Conservation. Ethiop. J. Of Biol. Sci, 1, 15-35.

Stirling, G. \& Wilsey, B. 2001. Empirical Relationships Between Species Richness, Evenness, And Proportional Diversity. The American Naturalist, 158, 286-299.

Tadele, D., Lulekal, E., Damtie, D. \& Assefa, A. 2014. Floristic Diversity And Regeneration Status Of Woody Plants In Zengena Forest, A Remnant Montane Forest Patch In Northwestern Ethiopia. Journal Of Forestry Research, 25, 329-336.

Tadesse M (2004) Asteraceae (Compositae). In: Hedberg I, Friis I, Edwards S (Eds) Flora Of Ethiopia And Eritrea, Vol (Vol 4-2). The National Herbarium, Addis Ababa, Pp 1-408

Teketay, D. 2005a. Seed And Regeneration Ecology In Dry Afromontane Forests Of Ethiopia: I. Seed ProductionPopulation Structures. Tropical Ecology, 46, 29-44.

Teketay, D. 2005b. Seed And Regeneration Ecology In Dry Afromontane Forests Of Ethiopia: Ii. Forest Disturbances And Succession. Tropical Ecology, 46, 45-64. 
Yeshitela, K. \& Bekele, T. 2003. The Woody Species Composition And Structure Of Masha Anderacha Forest, Southwestern Ethiopia. Ethiopian Journal Of Biological Sciences, 2, 31-48.

Zegeye, H., Teketay, D. \& Kelbessa, E. 2011. Diversity And Regeneration Status Of Woody Species In Tara Gedam And Abebaye Forests, Northwestern Ethiopia. Journal Of Forestry Research, 22, 315.

Submitted: 21.09.2019 Accepted: 16.02.2020 